\title{
Earliest occurrence of the Hirnantia Fauna in the Prague Basin (Czech Republic)
}

\author{
MICHAL MERGL
}

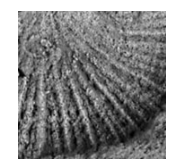

\begin{abstract}
The Hirnantia Fauna was observed at a new stratigraphic level in the topmost Králův Dvůr Formation at Praha-̌̌eporyje. Up to now this distinctive late Ordovician fauna has been known only from the summit of the Kosov Formation in the Prague Basin. The newly observed fauna consists of draboviids Hirnantia sagittifera, Kinnella kielanae kielanae, taxonomically poor ostracods, a machaeridian Lepidocoleus, a new undetermined carpoid, and the very rare Mucronaspis. The fauna is much poorer than the fauna of the 'Perník Bed' below. The presence of the Hirnantia Fauna at this new level indicates a significant cooling and eustatic fall in the sea level resulting in a shallow subtidal environment (BA 3-4) prior to the deposition of glaciomarine diamictites at the base of the Kosov Formation. - Key words: Hirnantia Fauna, Hirnantia, Kinnella, Ordovician, Hirnantian, Králův Dvůr Formation, Prague Basin.
\end{abstract}

Mergl, M. 2011. Earliest occurrence of the Hirnantia Fauna in the Prague Basin (Czech Republic). Bulletin of Geosciences 86(1), 63-70 (3 figures). Czech Geological Survey, Prague. ISSN 1214-1119. Manuscript received November 11, 2010; accepted in revised form January 24, 2011; published online February 22, 2011; issued March 14, 2011.

Michal Mergl, Department of Biology, Faculty of Education, University of West Bohemia in Plzeň, Klatovská 51, 30619 Plzen̆, Czech Republic; mmergl@kbi.zcu.cz.

The Hirnantia Fauna is a distinctive widespread brachiopod fauna in the terminal Ordovician Hirnantian Stage. Since recognition of this distinctive fauna by Temple (1965) many authors have considered various aspects of the Hirnantia Fauna. There have been in particular contributions regarding its systematics (Temple 1965, Bergström 1968, Lespérance \& Sheehan 1976, Havlíček 1977, Hiller 1980, Cocks 1982, Mélou 1987, Harper et al. 1994, Rong \& Li 1999), palaeogeography (Wright 1968, Rong et al. 1984, Havlíček 1990, Owen et al. 1991, Cocks \& Fortey 2002, Chen et al. 2003, Rong et al. 2006), palaeobathymetry (Brenchley \& Cocks 1982, Brenchley \& Cullen 1984, Owen et al. 1991), extinction (Sheehan 2001; Rong et al. 2002, 2006; Rong \& Shen 2002; Cocks \& Rong 2008) and also many other aspects. Syntheses of the Hirnantia Fauna were published by Rong \& Harper (1988, 1999).

The Hirnantia Fauna, although widespread, is not a cosmopolitan one because it is absent in the tropical belt. Two Ordovician provinces with the Hirnantia Fauna have been recognized: the circumpolar cold Bani province with an atypical restricted fauna, and the temperate to the subtropical Kosov province with the typical, rich Hirnantia Fauna. The coeval tropical Edgewood province shows a different brachiopod fauna (Rong \& Harper 1988).
Repository. - All figured specimens are housed in the palaeontological collections of the Geological Survey, Prague (MM).

\section{The Hirnantia Fauna in the Prague Basin}

The first comprehensive report on the distinctive Hirnantia Fauna in Bohemia is in Marek \& Havlíček's (1967) publication. They described nineteen species of rhynchonelliform brachiopods from the topmost part of the Kosov Formation at Nová Ves and Běchovice near Prague (Fig. 1). Some of those species were described in more detail or revised by Havlíček (1967, 1977). Subsequent taxonomical contributions indicate the presence of five lingulate and craniate brachiopods in the Bohemian Hirnantia Fauna (Mergl 1986, Havlíček 1994). Marek \& Havlíček (1967) had also already noted the presence of bryozoans, trilobites, crinoids, gastropods, bivalves and other invertebrate groups, but, with the exception of gastropods (Marek 1963) and bivalves (Křiž \& Steinová 2009), these groups have not been taxonomically revised up to now. In the last decades, a few new occurrences of the Hirnantia Fauna were observed in territory of Prague: Prague-Pankrác (Štěpánek 1984), Prague-Řepy (Štorch 1982), Prague-Nové Butovice (Štorch 1991), Prague-Velká Ohrada (Štorch 1994), 

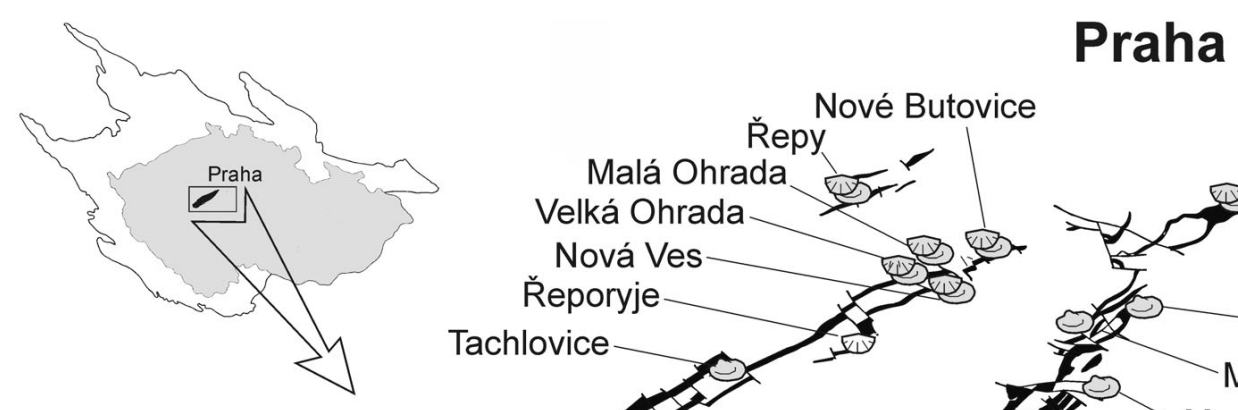

Bèchovice
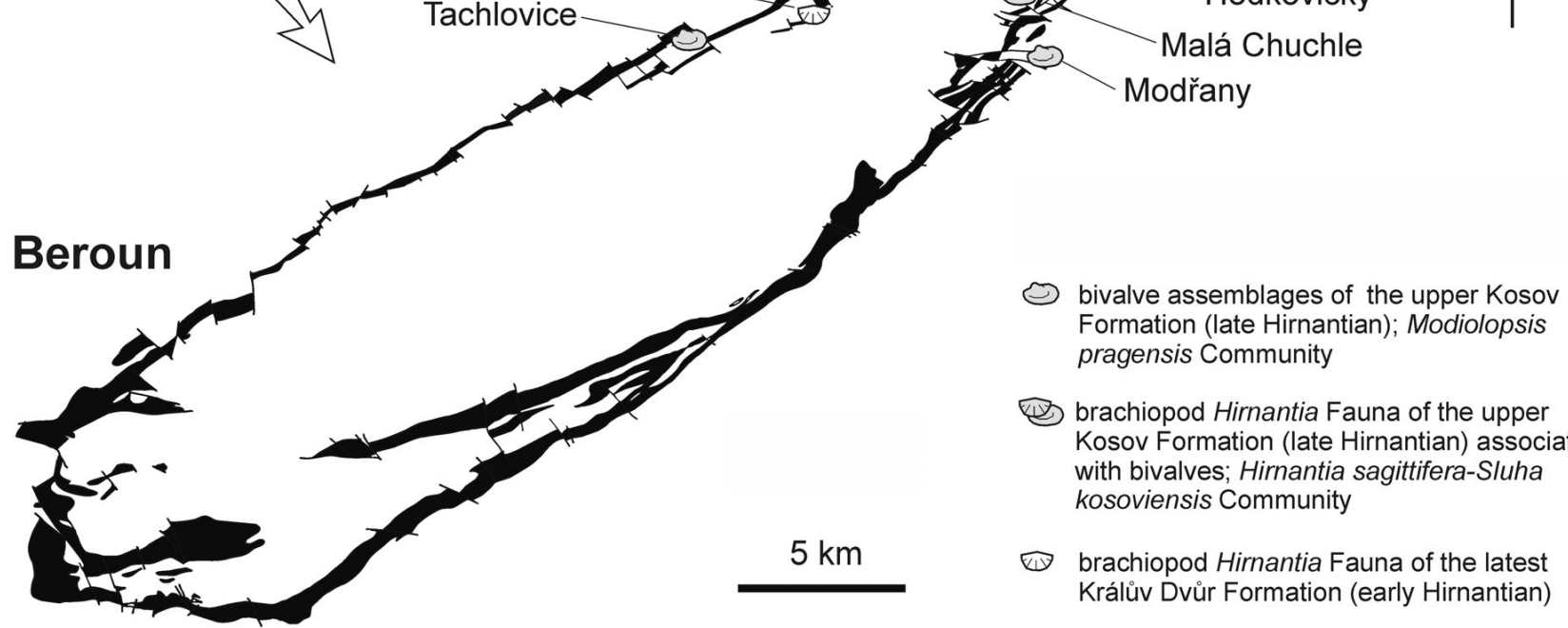

Figure 1. Distribution of the Kosov Formation (Hirnantian) in the Prague Basin of the Czech Republic, the location of the localities with the Hirnantia Fauna and bivalve fauna at the top of the Kosov Formation, and the new locality with the Hirnantia Fauna at the top of the Králův Dvůr Formation (after Křǐž \& Steinová 2009, modified).

Prague-Malá Ohrada, and Prague- ̌̌eporyje (both unpublished). All the occurrences of the Hirnantia Fauna are confined to the NE part of the Prague Basin in the vicinity of Prague. The fauna is usually restricted to a less than $1 \mathrm{~m}$ succession at the summit of the Kosov Formation within the Normalograptus persculptus Biozone (Štorch 1982).

In the Prague Basin this taxonomically rich association of the Hirnantia fauna appeared above a much poorer, mostly bivalve dominated association. The two associations are separated by an interval of unfossiliferous shales and storm-generated sandstones.

A new interpretation of the earlier sources (Marek 1951, Štorch 1986a), taxonomic revision, and new observations led Kř́ř \& Steinová (2009) to recognitise the Modiolopsis pragensis Community in the upper part of the Kosov Formation. This community is dominated by the eponymous bivalve associated with rare gastropods, brachiopods, rostroconchs and the trilobite Brongniartella. It is followed by the Hirnantia sagittifera-Sluha kosoviensis Community, which represents a more offshore and taxonomically rich benthic association. The succession from a bivalve-dominated association to a more diverse brachiopod-dominated association on the basin floor has been assigned to a eustatic rise of sea level (Štorch 1986b) caused by progressive melting of the southern polar ice cap.
The taxonomic diversity of the Hirnantia sagittifera-Sluha kosoviensis Community is remarkably rich and may be compared with the Eostrophomena-Hirnantia Community described by Rong (1986) and Chen et al. (2003) from the Yangtze region of South China. This similarity indicates the position of the Prague Basin and Perunica in a temperate belt of the Kosov Province in the late Hirnantian. In summary, the distribution and taxonomic composition of the Hirnantia Fauna in Bohemia indicates shallow oxygenated water, rich in nutrients in an upper subtidal environment (BA 3).

However, from a stratigraphical point of view, the so far reported occurrence of the Hirnantia Fauna in the Prague Basin has been very late (Rong et al. 2002). Most of its occurrences outside the Prague Basin, although diachronnous, indicate an earlier appearance of this distinctive fauna, already present in the early Normalograptus ojsuensis and/or Normalograptus extraordinarius Biozone with Hirnantia sagittifera and Plectothyrella crassicosta extending from the latest Paraorthograptus pacificus Biozone (Rong et al. 2002).

Environmental and lithological changes and their impact on benthic associations around the Katian/Hirnantian boundary have been summarized by Štorch \& Mergl (1989). In the Prague Basin the position of the Katian/Hirnantian boundary was located by Štorch (1990) as in the bed with the Mucronaspis Community, just above 


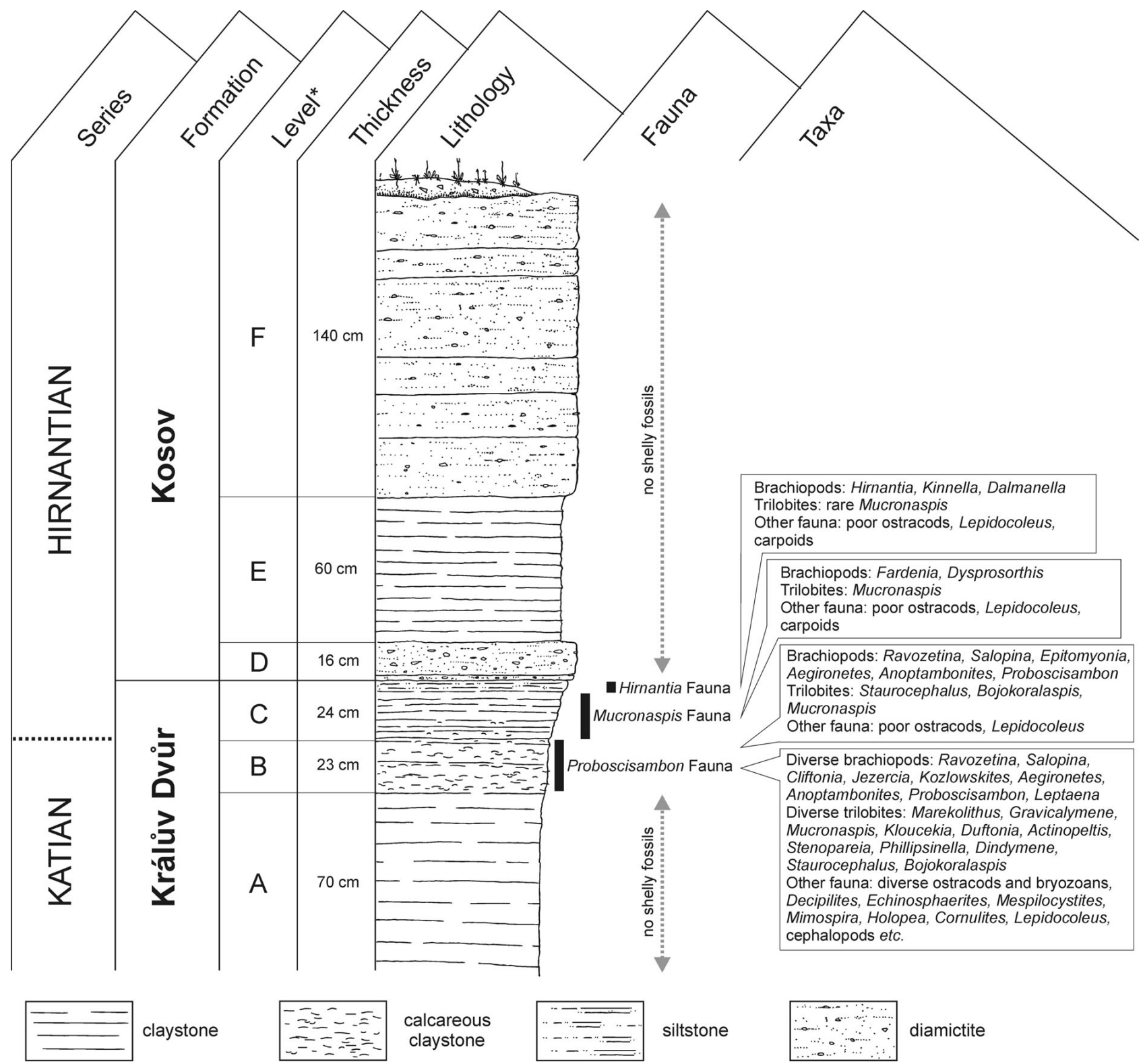

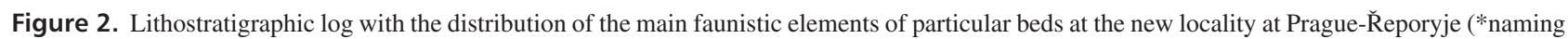
of levels are in sense of Štorch \& Mergl 1989).

the 'Perník Bed' at the summit of the Králův Dvůr Formation. This location could be justified by the rapid cooling and environmental deterioration in the basin as well as the by presence of Normalograptus ojsuensis in beds bearing the Mucronaspis Fauna (Štorch 1990). He also suggested that the Mucronaspis Fauna occupied deeper water (BA 4-5) than the Hirnantia Fauna. It has been presumed that the climatic changes destroyed the Mucronaspis Fauna due to the succeeding influx of glacio-marine diamictites (Štorch 1990). The last Mucronaspis is known from siltstones between two diamictite layers (Brenchley \& Štorch 1989). Based on these considerations, it could be suggested that before deposition of the diamictites marking the base of the Kosov Formation, the now preserved basin floor was below the depth range of the shelly Hirnantia Fauna.

\section{New locality with the Hirnantia Fauna}

Recently, shells of the brachiopods Hirnantia sagittifera (M'Coy, 1851) and Kinnella kielanae (Temple, 1965) were found during laboratory investigation of claystones and siltstones yielded from a small temporary outcrop opened in 2003 at Prague- ̌̌eporyje. The shells indicate a much earlier appearance of the Hirnantia Fauna in the Prague Basin than had been previously suggested (Fig. 2). 
Outcropping rocks at the new locality (Fig. 1) show a rather monotonous lithology, starting with a richly fossiliferous bed, $23 \mathrm{~cm}$ thick decalcified claystone (equivalent to the 'Perník Bed' of Štorch \& Mergl 1989 a.o.) overlaid by two grey-green, coarsing upward claystone and shale beds with scattered quartz grains (Fig. 2). These $24 \mathrm{~cm}$ thick beds of claystone and shale are followed by the first diamictite bed. The diamictite bed is divided by a clay lamina into 2 beds, a lower $2 \mathrm{~cm}$ thick and an upper $14 \mathrm{~cm}$ thick, respectively. The overlying $60 \mathrm{~cm}$ of grey-green siltstone without fossils is followed by major diamictite bed of unknown total thickness (the measured incomplete thickness is more than one metre). The lithology is comparable with those in other localities of the same stratigraphic level (Štorch \& Mergl 1989).

The lowest bed correlates with level B of Štorch \& Mergl (1989), having the same rich brachiopod and trilobite fauna (Fig. 2). The following claystone and shale correspond to level $\mathrm{C}$. The first diamictite bed could be correlated with level D. This lithological criteria correlate well with the fossil content (Fig. 2).

The lowest bed (level B) yielded a very rich brachiopods content, mostly plectambonitaceans, and trilobites known in other localities of the Marekolithus kosoviensis Horizon. Noteworthy is the commonness of bryozoans, hyoliths and machaeridians. The upper part of level B formed by pale claystone is characterised by the abundance of the trilobite Staurocephalus clavifrons associated with small dalmanellacean and plectambonitacean brachiopods, represented by Aegironetes, Anoptambonites, Epitomyonia and Salopina. This upper part of level B is only $2-5 \mathrm{~cm}$ thick. The overlying grey-green claystone and shale of level C is rich in ostracods, fragments of the trilobite Mucronaspis, sclerites of the machaeridian Lepidocoleus, isolated plates of carpoids, and rare very small dalmanellaceans. The plectambonitaceans are absent. This level displays a rapid decrease of taxonomic diversity compared with level B. Mucronaspis, the only trilobite at this level, is often preserved as small fragments and juvenile sclerites, including a pygidia smaller than $5 \mathrm{~mm}$. The fossil association represents the Mucronaspis Community sensu Štorch \& Mergl (1989).

A 5 to $7 \mathrm{~cm}$ thick layer of siltstone with scattered quartz grains, yielding a distinct fauna, is situated immediately below the first diamictite layer. Poorly diversified ostracods, sclerites of machaeridians, and isolated are significant. Small to medium sized shells of Kinnella kielanae kielanae are the commonest among the brachiopods. The draboviid Hirnantia sagittifera and the small dalmanellid Ravozetina have only rarely been collected. In contrast to the layers below, the absence of plectambonitaceans is conspicuous. This bed has no equivalent in previously measured sections (Štorch \& Mergl 1989) and represents the earliest appearance of the Hirnantia Fauna in the Prague Basin.

\section{Taphonomy of the new Hirnantia Fauna}

All the fossils in the layer with the Hirnantia Fauna are highly fragmented, with the exception of highly convex, thick-walled ostracod shells, which are often clustered and almost intact. Sclerites of the machaeridian Lepidocoleus and plates of carpoids are always isolated, some of them broken. The trilobite Mucronaspis is known from very rare small fragments. Brachiopod shells are always disarticulated, mostly crushed into 2-3 $\mathrm{mm}$ or even smaller fragments. Complete brachiopod valves represent $20-30 \%$ of the total preserved valves. Shell fragments are not sorted, worn, abraded or collapsed, indicating rapid transport and deposition without winnowing, significant compression and dissolution in the sediment. Shales and siltstones including the bed with the Hirnantia Fauna have been interpreted by Štorch (2006) as possible distal storm deposits. In summary, the shells represent material transported over some distance and rapidly deposited.

\section{Systematic part}

Order Orthida Schuchert \& Cooper, 1932

Superfamily Enteletoidea Waagen, 1884

Family Draboviidae Havlíček, 1950

Subfamily Draboviinae Havlíček, 1950

\section{Genus Hirnantia Lamont, 1935}

Type species. - Orthis sagittifera M'Coy, 1851; Hirnantian; Scotland.

\section{Hirnantia sagittifera (M'Coy, 1851)}

Figure 3J-L

Remarks. - Hirnantia sagittifera (M'Coy, 1851) is a large draboviid having a poorly defined dorsal sulcus, deep dorsal valve with simple cardinal process, strong diverging dental plates, and multicostellate ornamentation with fine radial capillae in intercostal furrows.

The new material is rare and fragmental, but shows some of the distinct features of $H$. sagittifera. The cardinal process is a simple ridge (Fig. 3L) and the multicostellate ornamentation with fine radial capillae in the bottom of intercostal furrows is striking even in small shell fragments (Fig. 3K). A few of the available shells are smaller, being only $8 \mathrm{~mm}$ in width. Some very small ventral valves with low interarea observed among the new shells could also belong to $H$. sagittifera. 


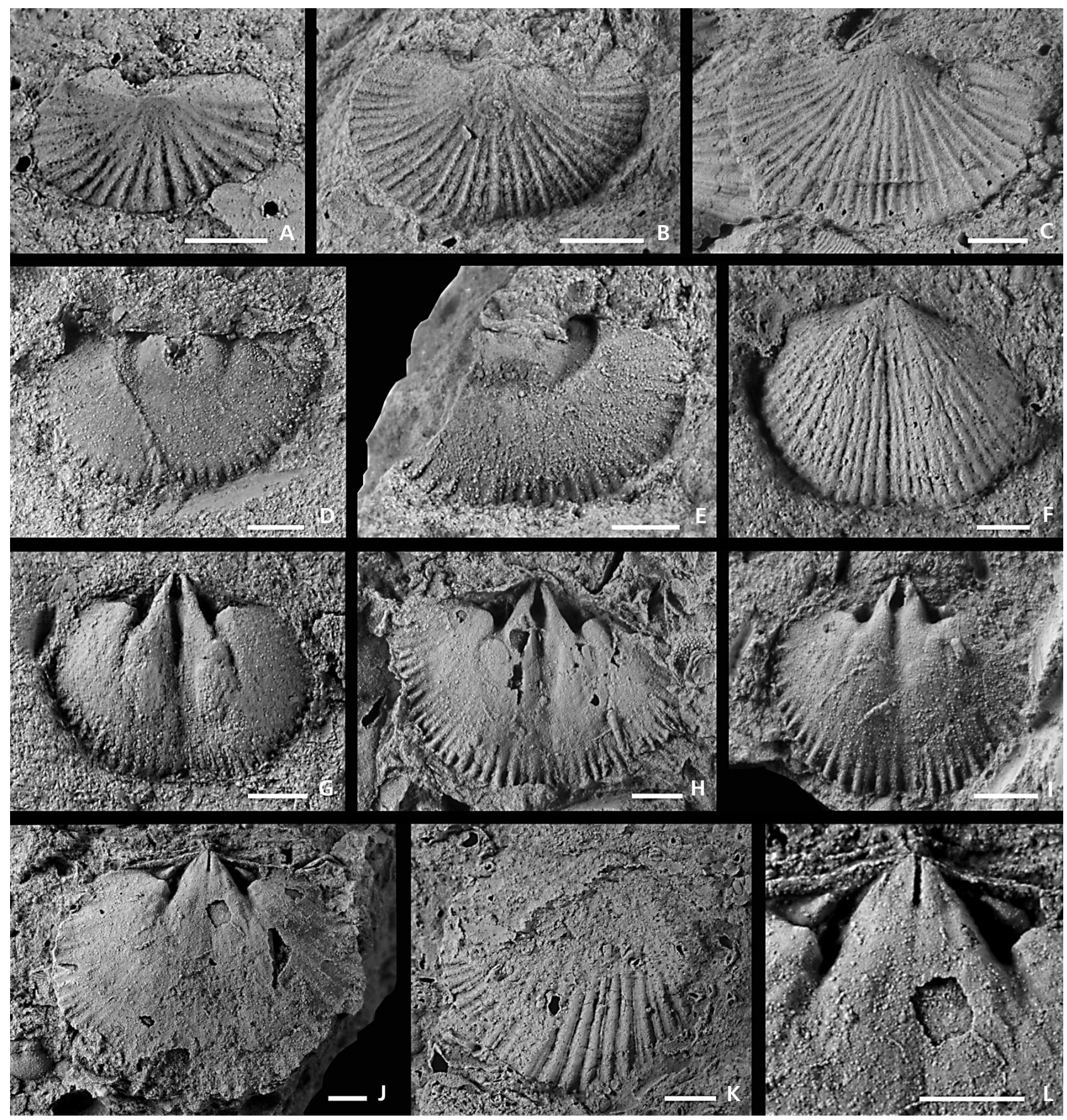

Figure 3. A-I - Kinnella kielanae kielanae (Temple, 1965). • A - small ventral valve, latex cast of exterior, MM 517. • B, E - ventral valve, latex cast of exterior and internal mould, MM 518. $\bullet \mathrm{C}$ - ventral valve, latex cast of exterior, MM 519. $\bullet$ D - small ventral valve internal mould, MM 520a. $\bullet$ F, G - dorsal valve, latex cast of exterior and internal mould, MM 521. $\bullet \mathrm{H}$ - dorsal valve internal mould, MM 520b. $\bullet$ I - dorsal valve internal mould, MM 522. - J-L - Hirnantia sagittifera (M'Coy, 1851), dorsal valve internal mould, latex cast of exterior, and detail of the cardinalia, MM 523. Stratigraphic and geographic location: The top of the Králův Dvůr Formation at Prague-řeporyje immediately below the first diamictite bed (topmost bed of level C in Fig. 2). Bars equal $1 \mathrm{~mm}$. All photos by the author.

Hirnantia sagittifera is the eponymous and distinct species of this latest Ordovician shelly fauna. It is known in many localities of Bani and Kosov provinces, with reports from Morocco, Bohemia, Hubei, Sichuan, Guizhou, Yunnan, Tibet, Percé, Maine, Scotland, Kazakhstan,
Wales, England, Ireland, Norway, Sweden, Poland, Sardinia, Spain and France (see Rong \& Harper 1988 for a review).

Occurrence in Bohemia. - Rare in Prague- ̌̌eporyje; 
abundant in the topmost Kosov Formation in Prague-Běchovice and Prague-Nová Ves (Havlíček 1977).

\section{Genus Kinnella Bergström, 1968}

Type species. - Hirnantia? kielanae Temple, 1965; Hirnantian; Poland.

Kinnella kielanae kielanae (Temple, 1965)

Figure 3A-I

Remarks. - Kinnella kielanae kielanae (Temple, 1965) is a small draboviid having a high catacline ventral interarea, moderately convex sulcate dorsal valve, multicostellate ornamentation with hollow ribs, and coarse internal costellation along the shell periphery (Bergström 1968). The cardinal process is apically bilobed and extending into the conspicuous median ridge. According to Havlíček (1977), the differences between $K$. kielanae kielanae (Temple, 1965) and K. kielanae proclinis (Havlíček, 1977) are at subspecies level. The differences are procline to catacline ventral interarea, divergent brachiophore supporting plates, and a straight, converging anterior border of the dorsal muscle field in K. kielanae proclinis. This subspecies is confined to the latest Hirnantian (N. persculptus Biozone) in the Prague Basin. With only two exceptions (Cocks \& Fortey 2002, Stott \& Jin 2007), all other foreign occurrences of Kinnella are referred to as K. kielanae kielanae. In a synthesis of the Hirnantia Fauna, the two subspecies were not discussed separately (Rong \& Li 1999).

The newly collected specimens (Fig. 3A-I) show all the features discussed by Havlíček (1977). The cardinal process is clearly bilobed. Dorsal valves manifest the rounded anterior margin of the dorsal muscle field, a feature distinct to K. kielanae kielanae (Temple 1965). In addition, because the ventral valves of the new specimens are not particularly tall and show only catacline ventral interarea (Fig. 3A), the new specimens are referred to the subspecies K. kielanae kielanae. Kinnella kielanae kielanae has been reported in many areas. A size-frequency distribution in a sample from Poland (Temple 1965) indicates the prevalence of 4-8 mm wide shells, with $11 \mathrm{~mm}$ sized specimens as the maximum. A similar distribution with 7 to $8 \mathrm{~mm}$ wide shells being the maximum was noted by Havlíček (1977) in K. kielanae proclinis. Widths of the newly collected entire valves ranged between 3 to $6 \mathrm{~mm}$, but fragments indicate even larger shells. In summary, there is no striking difference in size between the newly collected shells and specimens from the foreign localities.

Kinnella kielanae is known from Wales (Temple 1965), Poland (Temple 1965), Norway (Brenchley \& Cocks 1982), Sweden (Bergström 1968), Carnic Alps (Jaeger et al. 1975), Sardinia (Villas in Leone et al. 1991),
Hubei (Rong 1979), Sichuan (Rong 1979), Guizhou (Rong 1979), Tibet (Rong \& Xu 1987), and Percé, Québec (Lespérance \& Sheehan 1976). The species is abundant in muddy substrates but not in the micritic muds (Rong \& Li 1999). Cocks \& Fortey (2002) separated the species Kinnella medlicotti (Reed, 1915) from the Hirnantian of Burma, and noted its probable presence in Hubei, China, although Temple (1965) postulated the possible identity of Reed's species as K. kielanae. Pre-Hirnantian (upper Katian) Kinnella laurentiana (Stott \& Jin 2007) from eastern North America differs by a more convex dorsal valve and less strongly apsacline ventral interarea.

Occurrence in Bohemia. - Abundant in Prague- ̌̌eporyje; absent from the topmost Kosov Formation where is substituted by Kinnella kielanae proclinis.

\section{Discussion}

New finds together with re-evalution of many published sources provide more precise dating of the first appearance of the Hirnantia Fauna in the Prague Basin. The Hirnantia Fauna of the typical Kosov province is characterized by the genera Dalmanella, Hirnantia, Kinnella, Paromalomena, Eostropheodonta, Cliftonia, Plectothyrella and Hindella. There are also other genera (in total some 45 rhynchonelliform genera; Rong \& Harper 1999), but their geographical distributions are more restricted. The Hirnantia Fauna diversified, after the first pulse of extinction during the early Hirnantian, before the N. persculptus Biochrone. The second pulse of extinction occurred during the early $N$. persculptus Biochrone and was not followed by any originations during the remaining part of this time period (Rong \& Harper 1999, Rong \& Shen 2002, Rong et al. 2002).

The draboviid Kinnella kielanae, the commonest brachiopod in the newly discovered fauna and Hirnantia sagittifera, the 'core' taxa of the Hirnantia fauna, indicate that the topmost beds of the Králův Dvůr Formation were deposited after the first extinction phase which hampered pre-Hirnantian shelly faunas. There are no records of Kinnella kielanae before this extinction (Rong et al. 2002). The first phase of the extinction, discussed in detail by Rong at al. (2002) started in the later P. pacificus Biochrone and continued during the $N$. extraordinarius-N. ojsuensis Biochrone.

\section{Conclusions}

The occurrence of the Hirnantia Fauna implies a progressive eustatic fall in the Prague Basin during the deposition of the highest beds of the Králův Dvůr Formation. During 
the fall, the depth of the basinal floor decreased allowing the associations of the Hirnantia Fauna (BA 3-4) to occupy the sea floor and substitute (at least locally) the poorly diversified and relatively deeper trilobite-dominated Mucronaspis Fauna (BA 4-5). It seems probable that this substitution was diachronnous. In the shallower marginal parts of the basin (Prague-Reporyje), the Hirnantia Fauna substituted the relatively deeper Mucronaspis Fauna. In the deepest part of the basin the Mucronaspis Fauna persisted until the first deposition of diamictites (level D). The same diamictite bed marks the end of the earliest Hirnantia Fauna in shallower parts of the basin. The start of the eustatic fall could be suggested to have occured during the deposition of the extremely fossiliferous 'Perník Bed' (level B) at the top of the Králův Dvurr Formation. However, these hypotheses need further confirmation and it is outside the scope of the present paper.

The presence of the Hirnantia Fauna in the topmost Králův Dvurr Formation and its recurrence at the summit of the Kosov Formation imply that the depth of the basin between these occurrences never substantially surpassed shallow subtidal, the suggested depth range of the Hirnantia Fauna.

\section{Acknowledgments}

The author is greatly indebted to Petr Budil (Geological Survey, Prague) for the loan of material and supply of important locality data, and to Enrique Villas (Zaragoza University, Zaragoza) and Petr Storch (Academy of Sciences of the Czech Republic, Prague) for critical reviews which substatially improved the quality of the text. The research was supported by a grant from the Academy of Sciences of the Czech Republic, IAA301110908: Faunistická dynamika klimaxového stádia společenstev svrchního ordoviku pred globální krizí způsobenou klimatickými změnami: záznam z králodvorského souvrstvi Barrandienu. This contribution forms part of a proposed IGCP project.

\section{References}

Bergström, J. 1968. Upper Ordovician Brachiopods from Västergötland, Sweden. Geologica et Palaeontologica 2, 1-35.

Brenchley, P.J. \& Cullen, B. 1984. The environmental distribution of associations belonging to the Hirnantia fauna - Evidence from North Wales and Norway, 113-125. In BRUTON, D.L. (ed.) Aspects of the Ordovician System. Palaeontological Contributions from the University of Oslo 295. Universitetsforlaget, Oslo.

Brenchley, P.J. \& Newall, G. 1984. Late Ordovician environmental changes and their effect on faunas, 65-79. In BRUTON, D.L. (ed.) Aspects of the Ordovician System. Palaeontological Contributions from the University of Oslo 295. Universitetsforlaget, Oslo.

BRENCHLEY, P.J. \& ŠToRCh, P. 1989. Environmental changes in the Hirnantian (upper Ordovician) of the Prague Basin, Czechoslovakia. Geological Journal 24, 165-181.

DOI 10.1002/gj.3350240302

Chen Xu, Rong Jia-yu, Li Yue \& Boucot, A.J. 2004. Facies patterns and geography of the Yangtze region, South China, through the Ordovician and Silurian transition. Palaeogeography, Palaeoclimatology, Palaeoecology 204, 353-372. DOI 10.1016/S0031-0182(03)00736-3

Cocks, L.R.M. 1982. The commoner brachiopods of the latest Ordovician of the Oslo-Asker District, Norway. Palaeontology 25(4), 755-781.

Cocks, L.R.M. \& ForTEY, R.A. 2002. The palaeogeographical significance of the latest Ordovician fauna from the PangshaPye Formation of Burma. Special Papers on Palaeontology 67, 57-76.

Cocks, L.R.M \& RONG JIA-YU 2008. Earliest Silurian faunal survival and recovery after the end Ordovician glaciation: evidence from the brachiopods. Earth and Environmental Science Transactions of the Royal Society of Edinburgh 98, 291-301.

Harper, D.A.T., Mitchell, W.I. \& Rong JiA-Yu 1994. New faunal data from the highest Ordovician rocks at Pomeroy, County Tyrone, Northern Ireland. Scottish Journal of Geology 30(2), 187-190. DOI 10.1144/sjg30020187

HavlíčEK, V. 1950. Ramenonožci českého ordoviku. Rozpravy Ústředního ústavu geologického 13, 1-72.

HAVLí̌̌EK, V. 1967. Brachiopoda of the suborder Strophomenidina in Czechoslovakia. Rozpravy Ústředního ústavu geologického 33, 1-235.

HAVLíčEK, V. 1977. Brachiopods of the order Orthida in Czechoslovakia. Rozpravy Ústředního ústavu geologického 44, $1-327$.

HavlíčEK, V. 1982. Ordovician in Bohemia: development of the Prague Basin and its benthic communitites. Sborník geologických věd, Geologie 37, 103-136.

HAVLí̌̌EK, V. 1989. Climatic changes and development of benthic communities through the Mediterranean Ordovician. Sborník geologických věd, Geologie 44, 179-116.

HAVLíčEK, V. 1990. Mediterranean and Malvinokafric Provinces: new data on the Upper Ordovician and Lower Silurian brachiopods. Časopis pro mineralogii a geologii 35(1), 1-13.

HAVLÍČEK, V. 1994. Kosovian inarticulate brachiopods and their ancestors (Late Ordovician, Prague Basin). Věstník Českého geologického ústavu 69(1), 59-67.

HiLLER, N. 1980. Ashgill Brachiopoda from the Glyn Ceiriog District, north Wales. Bulletin of the British Museum (Natural History), Geology 34(3), 109-216.

JAEGER, H., HAVlíčEK, V. \& SChÖNLAuB, H.P. 1975. Biostratigraphie der Ordovizium/Silur-Grenz in der Südalpen - Ein beitrag zur discussion um die Hirnantia-Fauna. Verhandlungen Geologische Bundesanstalt A 4, 271-189.

KŘiž, J. \& SteinovÁ, M. 2009. Uppermost Ordovician bivalves from the Prague Basin (Hirnantian, Perunica, Bohemica). Bulletin of Geosciences 84(3), 409-436. DOI 10.3140/bull.geosci.1141

Lamont, A. 1935. The Drummuck Group, Girvan; a stratigraphic revision, with description of new fossils from the lower part of the group. Geological Society of Glasgow, Transactions 19, 288-334. 
Leone, F., Hammann, W., Laske, R., Serpagli, E. \& Villas, E. 1991. Lithostratigraphic units and biostratigraphy of the postSardic Ordovician sequence in south-west Sardinia. Bollettino della Società Paleontologica Italiana 30(2), 201-235.

Lespérance, P.J. \& Sheehan, P.M. 1976. Brachiopods from the Hirnantian stage (Ordovician-Silurian) at Percé, Quebec. Palaeontology 19(4), 716-731.

MAREK, L. 1951. Nové nálezy ve vrstvách kosovských $\left(\mathrm{d} \xi_{2}\right)$. Sborník Ústředního ústavu geologického 18, 1-12.

MareK, L. 1963. Bellerophontid gastropods in the Kosov Beds (Ordovician) of Bohemia. Věstník Ústředního ústavu geologického 28, 273-276.

MAREK, L. \& HAVLíčEK, V. 1967. The articulate brachiopods of the Kosov Formation (Upper Ashgill). Věstník Ústředního ústavu geologického 42, 275-284.

M'Coy, F. 1851. On some new Cambro-Silurian fossils. Annals and Magazine of Natural History (series 2) 8, 387-409.

Mélou, M. 1987. Découverte de Hirnantia sagittifera (M'Coy, 1851) (Orthida, Brachiopoda) dans l'Ordovicien supérieur (Ashgillien) de l'extrémité occidentale du Massif Armoricain. Geobios 20(5), 679-685.

DOI 10.1016/S0016-6995(87)80022-0

Mergl, M. 1986. Craniopsidae (Inarticulata, Brachiopoda) in the Ordovician-Silurian sequence of the Prague Basin (Bohemia). Věstník Ústředního ústavu geologického 61, 183-186.

Owen, A.W., Harper, D.A.T. \& Rong JiA-Yu 1991. Hirnantian trilobites and brachiopods in space and time, 179-190. In Barnes, C.R. \& Williams, S.H. (eds) Advances in Ordovician Geology, Geological Survey of Canada, Paper 90-9.

REED, F.R.C. 1915. Supplementary memoir on new Ordovician and Silurian fossils from the Northern Shan States. Palaeontologia Indica (New Series) 6(1), 1-98.

RoNG JIA-YU 1979. The Hirnantia fauna of China with the comments on the Ordovician-Silurian boundary. Acta Stratigraphica Sinica 3(1), 1-29.

Rong JiA-YU 1984. Distribution of the Hirnantia fauna and its meaning, 101-112. In BRUTON, D.L. (ed.) Aspects of the Ordovician System. Palaeontological Contributions from the University of Oslo 295. Universitetsforlaget, Oslo.

Rong JIA-YU 1986. Ecostratigraphy and community analysis of Late Ordovician and Silurian in southern China, 1-24. In Palaeontological Society of China (ed.) Selected papers of the $13^{\text {th }}$ and $14^{\text {th }}$ Annnual Convention of the Palaeontological Society of China. Anhui Science and Technology Publishing House, Hefei.

Rong JiA-Yu, Chen Xu \& Harper, D.A.T. 2002. The latest Ordovician Hirnantia Fauna (Brachiopoda) in time an space. Lethaia 35, 231-249. DOI 10.1080/00241160260288820

Rong JiA-YU \& HARPER, D.A.T. 1988. A global synthesis of the latest Ordovician Hirnantian brachiopod faunas. Transactions of the Royal Society of Edinburgh, Earth Sciences 79, 383-402.

Rong JiA-YU \& HARPER, D.A.T. 1999. Brachiopod survival and recovery from the latest Ordovician mass extinction in South China. Geological Journal 34, 321-348.

DOI 10.1002/(SICI)1099-1034(199911/12)34:4<321::AIDGJ809>3.0.CO;2-I

Rong JiA-YU \& Li Rong-YU 1999. A silicified Hirnantia Fauna (latest Ordovician brachiopods) from Guizhou, Southwest China. Journal of Paleontology 73(5), 831-849.
Rong JiA-Yu \& SHEN SHU-ZHOng 2002. Comparative analysis of the end-Permian and end-Ordovician brachiopod mass extinctions and survival in South China. Palaeogeography, Palaeoclimatology, Palaeoecology 188, 25-38. DOI 10.1016/S0031-0182(02)00507-2

Rong JiA-YU \& Xu HAN-ku 1987. Terminal Ordovician Hirnantia Fauna of the Xainza district, northern Xizang. Bulletin of Nanjing Institute of Geology and Palaeontology, Academia Sinica 11, 1-19.

Rong Jia-yu, Boucot, A.J., Harper, D.A.T., Zhan Ren-Bin \& Neuman, R.B. 2006. Global analyses of brachiopod faunas through the Ordovician and Silurian transition: reducing the role of the Lazarus effect. Canadian Journal of Earth Sciences $43,21-39$.

Schuchert, C. \& CoOper, G.A.1932. Brachiopod genera of the suborders Orthoidea and Pentameroidea. Memoirs of the Peabody Museum of Natural History 4(1), xii+1-270.

Sheehan, P.M. 2001. The late Ordovician mass extinction. Annual Reviews of Earth and Planetary Sciences 29, 331-364. DOI 10.1146/annurev.earth.29.1.331

Stotт, C.A. \& Jisuo Jin 2007. The earliest known Kinnella, an orthide brachiopod from the Upper Ordovician of Manitoulin Island, Ontario, Canada. Acta Palaeontologica Polonica 52(3), 535-546.

ŠTĚPÁNEK, P. 1984. Geologie pankrácké štoly. Unpublished report, Czech Geological Survey, Prague.

S̆TORCH, P. 1982. Ordovician-Silurian in the northernmost part of the Prague Basin (Barrandian, Bohemia). Věstník Ústředního ústavu geologického 57(4), 231-236.

S̆TORCH, P. 1986a. Ordovician-Silurian boundary in the Prague Basin (Barrandian area, Bohemia). Sborník geologických věd, Geologie 41, 69-103.

S̆TORCH, P. 1986b. Ordovician-Silurian boundary event in Bohemia (Prague basin-Barrandian area), 133-138. In WALLISER, O. (ed.) Lecture Notes in Earth Sciences. Springer-Verlag Berlin, Heidelberg.

ŠTORCH, P. 1990. Upper Ordovician - lower Silurian sequences in the Bohemian Massif, central Europe. Geological Magazine 127, 225-239. DOI 10.1017/S0016756800014503

ŠTorch, P. 1991. Faciální vývoj, stratigrafie a korelace svrchního ordoviku a spodního siluru pražské pánve (Barrandien). Unpublished Ph.D. thesis, Czech Geological Survey, Prague.

S̆тоRCH, P. 1994. Llandovery-Wenlock boundary beds in the graptolite-rich sequence of the Barrandian area (Bohemia). Journal of the Czech Geological Society 39, 163-182.

ŠTorCh, P. \& Mergl, M. 1989. Králodvor/Kosov boundary and the late Ordovician environmental changes in the Prague Basin (Barrandian area, Bohemia). Sborník geologických věd, Geologie 44, 117-153.

Temple, J.T. 1965. Upper Ordovician brachiopods from Poland and Britain. Acta Palaeontologica Polonica 10(3), 379-427.

WaAgen, W. 1884. Salt Range fossils, vol. I. Productus-Limestone fossils, Brachiopoda. Memoirs of the Geological Survey of India, Palaeontologica Indica (series 13), fasc. 4(3-4), 547-728.

Wright, A.D. 1968. A westward extension of the Upper Ashgillian Hirnantia Fauna. Lethaia 1, 352-367.

DOI 10.1111/j.1502-3931.1968.tb01626.x 